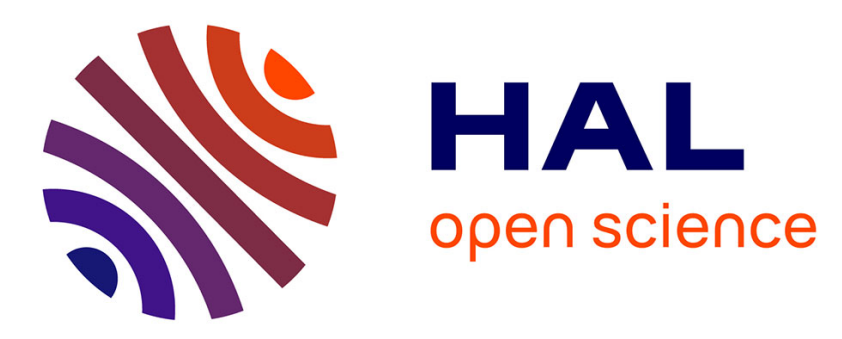

\title{
Evaluation of three simple direct or indirect carbonyl detection methods for characterization of oxidative modifications of proteins
}

Veronica R Vasquez-Garzon, Patrick Rouimi, Isabelle Jouanin, Georg Waeg, Neven Zarkovic, Saul Villa-Trevino, Françoise Guéraud

\section{To cite this version:}

Veronica R Vasquez-Garzon, Patrick Rouimi, Isabelle Jouanin, Georg Waeg, Neven Zarkovic, et al.. Evaluation of three simple direct or indirect carbonyl detection methods for characterization of oxidative modifications of proteins. Toxicology Mechanisms and Methods, 2012, 22 (4), pp.296-304. 10.3109/15376516.2012.657258 . hal-01136991

\section{HAL Id: hal-01136991 https://hal.science/hal-01136991}

Submitted on 30 Mar 2015

HAL is a multi-disciplinary open access archive for the deposit and dissemination of scientific research documents, whether they are published or not. The documents may come from teaching and research institutions in France or abroad, or from public or private research centers.
L'archive ouverte pluridisciplinaire HAL, est destinée au dépôt et à la diffusion de documents scientifiques de niveau recherche, publiés ou non, émanant des établissements d'enseignement et de recherche français ou étrangers, des laboratoires publics ou privés. 


\title{
Evaluation of three simple direct or indirect carbonyl detection methods for characterization of oxidative modifications of proteins
}

\author{
Verónica R. Vásquez-Garzón ${ }^{1, *}$, Patrick Rouimii, ${ }^{2, *}$, Isabelle Jouanin², Georg Waeg³, \\ Neven Zarkovic ${ }^{4}$, Saul Villa-Treviño ${ }^{1}$, and Françoise Guéraud ${ }^{2}$ \\ ${ }^{1}$ Departamento de Biología Celular, Centro de Investigación y de Estudios Avanzados del IPN, México D.F., México, \\ ${ }^{2}$ INRA, UMR 1331-TOXALIM, Research Centre in Food Toxicology Toulouse, France, ${ }^{3}$ Institute of Molecular Biosciences, \\ University of Graz, Graz, Austria, and ${ }^{4}$ Division of Molecular Medicine, Rudjer Boskovic Institute, Zagreb, Croatia
}

\begin{abstract}
Among disruptions induced by oxidative stress, modifications of proteins, particularly irreversible carbonylation, are associated with the development of several diseases, including cardiovascular diseases, neurodegenerative diseases, and cancer. Carbonylation of proteins can occur directly or indirectly through the adduction of lipid oxidation products. In this study, three classical and easy-to-perform techniques to detect direct or indirect carbonylation of proteins were compared. A model protein apomyoglobin and a complex mixture of rat liver cytosolic proteins were exposed to cumene hydroperoxide oxidation or adduction to the lipid peroxidation product 4-hydroxynonenal in order to test direct or indirect carbonylation, respectively. The technique using a specific anti-4-hydroxynonenalhistidine adduct antibody was effective to detect in vitro modification of model apomyoglobin and cytosolic proteins by 4-hydroxynonenal but not by direct carbonylation which was achieved by techniques using biotincoupled hydrazide or dinitrophenylhydrazine derivatization of carbonyls. Sequential use of these methods enabled the detection of both direct and indirect carbonyl modification in proteins, although constitutively biotinylated proteins were detected by biotin-hydrazide. Although rather classical and efficient, methods for carbonyl detection on proteins in oxidative stress studies may be biased by some artifactual detections and complicated by proteins multimerizations. The use of more and more specific available antibodies is recommended to complete detection of lipid peroxidation product adducts on proteins.
\end{abstract}

Keywords: Protein carbonyls, 4-hydroxynonenal, lipid peroxidation, biotin-hydrazide, dinitrophenylhydrazine

\section{Introduction}

Oxidative stress occurs when the levels of intracellular reactive oxygen species (ROS) exceed the detoxification capacity of the cell. It induces disruption of redox regulation trough disturbances in cell signaling and protein-protein interactions and damages macromolecule. Oxidative protein modifications play central role in major human diseases, such as atherosclerosis, diabetes, cardiovascular diseases, cancer, neurodegenerative disorders, and chronic liver and lung diseases (Nystrom 2005; Valko et al. 2007; Waris and Ahsan 2006; NegreSalvayre et al. 2010). Oxidative stress induces significant biological damage in cells through the modification of DNA, proteins, lipids, and carbohydrates. In proteins, the modification can be induced directly by ROS or indirectly by reaction of intermediates due to oxidation of other cellular components, such as lipids or carbohydrates, yielding advanced lipoxidation or glycation end products.

*Verónica R. Vásquez-Garzón and Patrick Rouimi contributed equally to this work.

Address for Correspondence: Patrick Rouimi, Institut National de la Recherche Agronomique (INRA), UMR 1331 TOXALIM (Research Centre in Food Toxicology), 180, Chemin de Tournefeuille, BP 93173, F-31027, Toulouse Cedex 3, France. Tel: (33) 561-385 393. Fax: (33) 561-385 244. E-mail: prouimi@toulouse.inra.fr

(Received 02 October 2011; revised 17 November 2011; accepted 19 November 2011) 


\section{Abbreviations}

$\mathrm{BH}$, Biotin-hydrazide

2DGE, two-dimensional gel electrophoresis

$\mathrm{DNPH}$, dinitrophenylhydrazine;

DTT, dithiothreitol

HNE, 4-hydroxynonenal
LC-ESI-MS, liquid chromatography-electrospray ionizationmass spectrometry

4-OTHP-HNE, 4-[(tetrahydro-2H-pyran-2-yl)oxy]-2(E)nonenal

ONE, 4-oxo-2(E)-nonenal

ROS, reactive oxygen species
Modification resulting in the addition of reactive functional carbonyl groups is called "protein carbonylation."

Radicals react directly with amino acids, such as arginine, threonine, proline, and lysine (Dalle-Donne et al. 2003), causing the formation of semi-aldehyde amino acids. Direct carbonylation of proteins can also arise through oxidative cleavage of proteins ( $\alpha$-amidation pathway or oxidation of glutamine side chains) (Aldini et al. 2007). Indirect carbonylation of proteins results from Michael addition of lipid peroxidation products involving $\alpha, \beta$-unsaturated aldehydes such as 4 -hydroxynonenal (HNE), 4-oxononenal (ONE), 2-propenal (acrolein) and the nucleophilic side chains of Cys, His, or Lys residues (Stadtman and Berlett 1997; Aldini et al. 2006) or by reaction of reactive carbonyl derivatives (ketoamines, ketoaldehydes, and deoxyosones) with lysine residues (Dalle-Donne et al. 2003).

Carbonylation is an irreversible, nonenzymatic modification of proteins. Protein carbonylation results in structural and conformational changes that lead to the malfunction of many enzymes, damage to membrane transporters, and impaired interactions with receptors. This modification is also related to the formation of protein cross-linkages; the resulting aggregates may accumulate in cells leading to degenerative diseases (Dalle-Donne 2006b). Carbonylation of specific amino acid side chains is one of the most abundant consequences of oxidative stress ( Requena et al. 2003).

One of the most abundant and toxic $\alpha, \beta$-unsaturated aldehyde product of omega- 6 polyunsaturated fatty acids is HNE. It is formed at basal concentrations under physiological conditions, and its cellular concentration ranges from 0.2 to $3 \mu \mathrm{M}$. Because HNE is an amphiphilic compound with strong lipophilic properties, it accumulates in biomembranes and reacts with phospholipids and membrane proteins (Poli et al. 2008), such as receptors and transporters. In addition, HNE has a wide range of biological activities, including inhibition of protein and DNA synthesis, disruption of $\mathrm{Ca}^{2+}$ homeostasis, membrane damage, cell death, and activation of stress signaling pathways. Most of these effects are thought to be mediated by covalent linking of HNE to proteins (Petersen and Doorn 2004; Poli et al. 2008). Previous works have shown that the C-3 carbon of HNE, which participates in the double bond, is a soft electrophilic center that interacts with the soft nucleophilic sulfur atom of cysteine. This carbon can also react with the imidazole nitrogen of histidine or, although to a lesser extent, the amine nitrogen of lysine to form Michael adducts (Esterbauer et al. 1991; Doorn and Petersen 2003; Grimsrud et al. 2008; LoPachin et al. 2009). Structures of HNE-protein adducts have been elucidated from chemical studies and also from in vitro or in vivo studies followed by complete acid or enzymatic hydrolysis and mass spectroscopic evaluation. Although HNE is much more reactive toward cysteine than histidine, it has been postulated that the HNE adduct of histidine is more stable than cysteine or lysine conjugates toward retro-Michael addition (Nadkarni and Sayre 1995; Doorn and Petersen 2002; Petersen and Doorn 2004; Sayre et al. 2006; Grimsrud et al. 2008; Lesgards et al. 2009).

Such Michael adducts have also been observed with thiol groups of glutathione. In model systems, mass spectrometric analysis has demonstrated that $>99 \%$ of proteins modified in vitro by HNE present a free carbonyl group (Bruenner et al. 1995). One of the most studied lipid peroxidation products in biological fluids or tissues is HNE, and it is now considered as one of the best ways to evaluate ongoing oxidative stress in vivo through measurement of HNE-protein adducts (Poli et al. 2008). Advanced methods are needed to elucidate the biological role of carbonyl protein modifications, the interplay of oxidative stress, and degradation of the oxidatively modified proteins as well as the molecular mechanisms involved in the development and progression of diseases. The methods must be in agreement with the projected objective, ensure practicality and reproducibility, and maintain the quality and quantity of the protein for further identification. Precise identification of modified sites constitutes an ultimate objective. Global approaches, such as proteomics, remain advantageous because they provide comparative information on the constant changing of the cell proteome through its biochemical interactions with the genome and environment. Thereby, proteomics is useful for identification of carbonylated proteins in a complex mixture.

Among several assays, which have been developed for detection of protein carbonyls, the most widely used involves derivatization of the carbonyl group with 2,4dinitrophenylhydrazine (DNPH) followed by detection of the stable hydrazone product formed 2,4-dinitrophenyl (DNP) (Levine et al. 1990). The DNP adduct can be detected by various techniques, including spectrophotometric assay (Levine et al. 1990, 1994), enzyme-linked immunosorbent assay (ELISA), and one-dimensional- or 
two-dimensional-electrophoresis coupled to western blot.

To select the best methods for protein carbonyl isolation from a complex mixture of proteins, the authors only used methods that allow for evaluation of the protein changes in one step without a priori digestion. These methods detect HNE-protein adducts using an anti-HNE-His antibody (Ab-HNE) or protein carbonyl derivatization with biotin-hydrazide $(\mathrm{BH})$, followed by streptavidin detection or 2, 4-DNPH and anti-DNP antibody detection. These methods, which can be easily used as they do not involve sophisticated techniques, allow the detection of whole proteins by electrophoresis methods. Here, easy, sensitive, and improved methods are presented and compared to detect direct and indirect protein carbonylation in the context of oxidative stress studies.

\section{Material and methods}

\section{Animals}

Male Wistar rats (230-250g) were obtained from Harlan, Granat, France. The rats had free access to water and to a semipurified diet (AIN 76, from UAR, Epinay, France). All experiments were performed in accordance with the institutional guidelines governing animal experimentation.

\section{Chemicals and reagents}

EZ-Link® Biotin Hydrazide, MES Buffer [(2-N-morpholino) ethanesulfonic acid] and desalting spin columns were from Pierce (Rockford, IL, USA). Myoglobin from equine heart, cumene hydroperoxide $(\mathrm{CH})$, and 2,4-DNPH were from Sigma Aldrich (St Quentin Fallavier, France). The Lowry assay kit for protein concentration determination was from Bio-Rad (Richmond, CA, USA). COMPLETE protease inhibitor cocktail tablets were provided by Roche Molecular Biochemicals (Mannheim, Germany). Anti-dinitrophenyl (Anti-DNP) antibody was from Sigma Aldrich. The mouse specific anti-HNE-His adducts antibody was a generous gift from Dr Waeg. It has been produced and tested as described (Waeg et al. 1996). The IRDye 800CW streptavidin and IRDye 800CW Goat anti-mouse antibodies were from Li-Cor Bioscience (Lincoln, NE, USA). The CF680 Goat anti-rabbit antibody was from Biotium (Hayward, CA, USA).

\section{HNE preparation}

The stable HNE precursor 4-[(tetrahydro- $2 H$-pyran-2 -yl)oxy]-2(E)-nonenal (4-OTHP-HNE) was synthesized according to a published method (Jouanin et al.2008). The protecting group tetrahydropyranyl (THP) was removed by dilution in methanol ( $150 \mu \mathrm{L}$ of a $10 \mathrm{mg} / \mathrm{mL}$ solution) and addition of PTSA (p-toluenesulfonic acid: $300 \mu \mathrm{L}$ of a $10 \mathrm{mg} / \mathrm{mL}$ solution in methanol). After stirring at room temperature for $3 \mathrm{~h}$, the methanol was evaporated and water was added. The HNE was extracted by methylene chloride, washed with brine, and dried with magnesium sulfate. The solution was evaporated and then $110 \mu \mathrm{L}$ of water was added. The concentration was determined by UV absorption (223 nm, $\left.\varepsilon 13750 \mathrm{~L} \cdot \mathrm{mol}^{-1} \cdot \mathrm{cm}^{-1}\right)$ of a diluted solution (1/1000 dilution).

\section{In vitro oxidation and adduction methods}

Apomyoglobin (APO) was prepared from horse heart myoglobin, which was dissolved in water ( 10 mg/ $\mathrm{mL}$ ) and precipitated in cold acetone containing $0.3 \%, 2 \mathrm{~N} \mathrm{HCl}$ for $30 \mathrm{~min}$ at $-20^{\circ} \mathrm{C}$. After centrifugation for $1 \mathrm{~min}$ at $1000 \times \mathrm{g}$, the precipitate was dried under a nitrogen stream and dissolved in ultra pure water. The bovine serum albuin (BSA) was directly dissolved in $50 \mathrm{mM}$ sodium phosphate, $\mathrm{pH}$ 7.4. Liver tissue samples $(\sim 100 \mathrm{mg})$ were homogenized in a $10 \mathrm{mM}$ HEPES buffer containing $137 \mathrm{mM} \mathrm{NaCl}, 4.6 \mathrm{mM} \mathrm{KCl}, 1.1 \mathrm{mM}$ $\mathrm{KH}_{2} \mathrm{PO}_{4}$, and $0.1 \mathrm{mM}$ EDTA, pH 7.4 and supplemented with $0.1 \mathrm{mM}$ PMSF and protease inhibitor cocktail prepared according to the manufacturer's directions. The cytosolic fraction was obtained from liver homogenates by successive centrifugations of $20 \mathrm{~min}$ at $14,000 \times g$ and $1 \mathrm{~h}$ at $100,000 \times g$. The soluble fraction was taken as the cytosol. Before in vitro oxidation, the different extracts were passed through desalting columns to replace the cellular fractionation buffer. The oxidation procedure was performed on $250 \mu \mathrm{g}$ of protein. Addition of HNE to APO, BSA and total proteins from liver cytosolic fraction was performed as described hereafter. The APO and BSA $(2 \mathrm{mg} / \mathrm{mL})$ were incubated for $2 \mathrm{~h}$ at $37^{\circ} \mathrm{C}$ or at room temperature in $50 \mathrm{mM}$ sodium phosphate buffer, $\mathrm{pH} 7.4$ containing $1.3 \mathrm{mM}$ HNE. Cytosolic proteins $(5 \mathrm{mg} / \mathrm{mL})$ were exposed to $2 \mathrm{mM} \mathrm{HNE}$ for $2 \mathrm{~h}$ at room temperature. Treatment with $\mathrm{CH}$ was carried out according to the previously described method of Arguelles et al. with minor modifications (Arguelles et al. 2006). Briefly, APO and protein extracts $(100 \mu \mathrm{g})$ were incubated for $20 \mathrm{~min}$ at $37^{\circ} \mathrm{C}$ with $1 \mathrm{mM} \mathrm{CH}$ in PBS.

\section{Carbonyl adducts detection}

Detection with $\mathrm{BH}$ reagent was adapted from the method described by Sayre et al. (2006) and Roe et al. (2007). Briefly, controlled and modified APO, BSA, and the cytosolic proteins were filtered on Sephadex G25 $(\varnothing 1 \times 10 \mathrm{~cm}$ column) or desalting spin columns equilibrated in $100 \mathrm{mM}$ sodium acetate buffer, $\mathrm{NaCl} 150 \mathrm{mM}, \mathrm{pH} 5.5$. Next, $50 \mathrm{mM}$ BH reagent in dimethylsulfoxide was added to a $1 \mathrm{mg} / \mathrm{mL}$ protein solution to yield a final concentration of $5 \mathrm{mM}$. Incubation was performed for $2 \mathrm{~h}$ at room temperature with vigorous mixing $(400 \mathrm{rpm})$. The controls were incubated with DMSO. Reaction with DNPH was performed according to the method described by Levine et al. (1994). Briefly, 40- $\mu$ g samples of control or modified proteins were incubated in $2 \mathrm{~N} \mathrm{HCl}$ additioned with 20 $\mu \mathrm{L}$ of $12 \%$ SDS and $200 \mu \mathrm{L}$ of $10 \mathrm{mM} \mathrm{DNPH}$ for $20 \mathrm{~min}$ at room temperature. After the reaction, the $\mathrm{pH}$ was neutralized with $2 \mathrm{M}$ Tris in $30 \%$ glycerol. The samples were 
then prepared for western blotting and two-dimensional electrophoresis.

\section{Western blotting}

Samples were boiled for $5 \mathrm{~min}$ in classical Laemmli buffer prior to western blotting. Proteins were separated by SDS-PAGE $(12.5 \%)$ at $200 \mathrm{~V}$ for about $1 \mathrm{~h}$ using the Mini-Protean III $^{\mathrm{m}}$ device (Bio-Rad) and then transferred to a Trans-Blot ${ }^{\circledR}$ Transfer Medium nitrocellulose membrane (Bio-Rad) using the Transblot-Blot ${ }^{\circledR}$ SD Semi-Dry Transfer Cell (Bio-Rad) at constant $250 \mathrm{~mA}(\sim 65 \mathrm{~V})$ for $2 \mathrm{~h}$ and $15 \mathrm{~min}$ in an ice bath. The membranes were blocked for $1 \mathrm{~h}$ at room temperature in PBS containing $0.1 \%$ Tween 20 and 5\% nonfat milk (blocking buffer) to avoid nonspecific labeling. The HNE-His protein adducts were detected on the blot after incubation with primary mouse anti-HNE-His antibody (1/100), followed by secondary goat anti-mouse antibody $(1 / 5000)$ coupled to IR-Dye ${ }^{\circledR}$ (Li-Cor Biosciences) under gentle agitation. Detection of carbonyl groups by $\mathrm{BH}$ was performed by incubating the blot membrane for $1 \mathrm{~h}$ at room temperature with streptavidin coupled to IR-Dye ${ }^{\circledR} 800 \mathrm{CW}$ (Li-Cor Biosciences) in a proportion of 1:10,000 in blocking buffer. Protein carbonyl groups were also detected by addition of 2,4DNPH and subsequent visualization of the formed 4-dinitrophenyl hydrazone (DNP) adducts. Blot membranes were successively incubated for $1 \mathrm{~h}$ at room temperature with a primary rabbit antibody (1:1000) specific for DNPprotein adducts (Sigma-Aldrich) followed by a secondary goat anti-rabbit antibody coupled to IR-Dye ${ }^{\circledR} 680$ (Li-Cor Biosciences) at 1:10,000 concentration in blocking buffer. Antibody dilutions were made in blocking buffer. The blots were scanned using an Odyssey Infrared Imaging System (Li-Cor Biosciences).

\section{Two-dimensional electrophoresis}

The protein concentration was estimated using the Lowry method (RC DC Protein Assay, Bio-Rad) or Amidoblack staining (Schaffner and Weissmann 1973). For the first dimension, protein samples $(100 \mu \mathrm{g})$ were loaded onto a 110-mm pH 3-10 ReadyStrip ${ }^{\text {mi }}$ IPG strip (BioRad, Marnes-La-Coquette, France) and covered with oil. Isoelectric focusing (IEF) was achieved on an Ettan IPGphor Isoelectric Focusing System (GE BiosciencesAmersham) by active rehydration for $18 \mathrm{~h}$ at $50 \mathrm{~V}$ in 125 $\mu \mathrm{L}$ of buffer containing $8 \mathrm{M}$ urea, $2 \%$ ampholytes, $10 \mathrm{mM}$ dithiothreitol (DTT), 2\% Chaps, and $2 \%$ bromophenol blue, followed by stepwise application of $50 \mathrm{~V}$ for $12 \mathrm{~h}$, $300 \mathrm{~V}$ for $1 \mathrm{~h}, 500 \mathrm{~V}$ for $1 \mathrm{~h}, 1000 \mathrm{~V}$ for $1 \mathrm{~h}$ and finally a linear gradient to $8000 \mathrm{~V}$ for $5 \mathrm{~h}$, for a total of at least $35,000 \mathrm{Vh}$ on the same instrument. The strips were stored at $-80^{\circ} \mathrm{C}$ until the second-dimension electrophoresis. For the second dimension, the strips were thawed and equilibrated with gentle shaking in an equilibration solution ( $50 \mathrm{mM}$ Tris$\mathrm{HCl}, 6 \mathrm{M}$ urea, $30 \%$ glycerol, $2 \% \mathrm{SDS}$, pH 8.8 ) with $1 \%$ DTT for $15 \mathrm{~min}$ and then in an equilibration solution with $2.5 \%$ iodoacetamide for $15 \mathrm{~min}$. The strips were loaded onto $12.5 \%$ SDS-PAGE gels; in addition, $3 \mu \mathrm{L}$ of PageRuler ${ }^{\mathrm{mm}}$ prestained molecular weight marker (Fermentas, SaintRémy-Lès-Chevreuse, France) was loaded against the IEF-strip before sealing with $0.5 \%$ agarose. Gels were run for $2 \mathrm{~min}$ at $250 \mathrm{~V}$ and then for $2 \mathrm{~h}$ at a constant voltage of $100 \mathrm{~V}$. Proteins were then transferred to nitrocellulose using the same protocol used for western blotting.

\section{Results}

Experiments using model proteins, that is, APO and BSA, and cellular cytosolic extracts were designed to improve the efficacy of two different modifying agents, $\mathrm{HNE}$ and $\mathrm{CH}$, in the formation of protein carbonyls. Three detection methods among the most routinely used techniques were tested and compared, namely histidine-HNE conjugate monoclonal antibody (Ab-HNE) immunodetection, $\mathrm{BH}$ derivatization followed by streptavidin detection and 2,4-DNPH conjugates.

\section{Comparison of the three methods for the detection of APO modifications by HNE and CH}

To evaluate the efficacy of the different detection methods for a pure protein, in vitro adduction by HNE and oxidation by $\mathrm{CH}$ on a model protein, APO, by detecting HNE adducts and carbonyl formation using western blotting was first investigated. As shown in Figure 1A, the formation of HNE adducts on APO (band at $17 \mathrm{kDa}$ ) after exposure to 4-HNE using the Ab-HNE, BH, or DNPH methods was clearly detected. Immunoreactive extra bands migrating close to 35 and $68 \mathrm{kDa}$ may represent the formation of dimers and tetramers, respectively, during the HNE-protein reaction in these experimental conditions. This generation of multimeric species is likely due to the formation of crosslinks between proteins because of the double reactivity of HNE, which can also undergo Michael additions with Cys, His, or Lys residues of one protein molecule and Schiff bases with the Lys residue of another (Roede et al. 2008). The absence of trimeric forms suggests that specific spatial conformations may be required for aggregation. As expected, oxidation of APO with $\mathrm{CH}$ did not induce the formation of HNE-His adducts, but $\mathrm{CH}$ was able to oxidize APO by a carbonylation process. Indeed, bands were detected using the $\mathrm{BH}$ and DNPH methods but not with Ab-HNE (Figure 1B). The observed bands are similar to those detected on HNE-treated APO, suggesting similar multimerization of the oxidized protein and confirming the involvement of carbonyl groups in this process.

\section{Detection of cytosolic proteins modified by in vitro treatment with $\mathrm{HNE}$ and $\mathrm{CH}$}

In vitro $\mathrm{HNE}$ modification and protein carbonylation of rat liver total cytosolic proteins were investigated using the same $\mathrm{Ab}-\mathrm{HNE}, \mathrm{BH}$, and DNPH methods, as described above for APO. An increase of HNE adducts as compared to basal level in proteins ranging in 
size from 25 to $250 \mathrm{kDa}$ was clearly detected with the Ab-HNE method combined with western blotting analyses (Figure 2A). In addition, the level of carbonylated proteins was increased by HNE treatment as observed when using the DNPH method. A pattern similar to that obtained with the $\mathrm{BH}$ method, but with slightly higher global intensity and specific band difference, such as the ones at $30-33 \mathrm{kDa}$ or $25 \mathrm{kDa}$, observed after HNE treatment was detected (Figure 2A). Because false positive results are possible with the $\mathrm{BH}$ method, detection using IRDyecoupled streptavidin on samples not treated with $\mathrm{BH}$ to evaluate the possible constitutive expression of biotinylated proteins in the cytosolic fractions was performed. Western blots revealed positive staining for the BH-untreated HNE-treated cytosolic proteins at two major bands of 70 and $120 \mathrm{kDa}$. Such staining was not observed for unbiotinylated model proteins (i.e., BSA and APO) (Figure 3). Western blot analysis after $\mathrm{CH}$ oxidation revealed reactive proteins ranging from 27 to $250 \mathrm{kDa}$ (Figure 2B). As expected Ab-HNE technique confirmed the inability of $\mathrm{CH}$ to induce the formation of HNE-His adducts on lipid-deprived cytosolic extracts (Figure 1B). In parallel, the $\mathrm{BH}$ and DNPH methods revealed that the carbonyl groups were quantitatively enhanced after $\mathrm{CH}$ treatment in comparison with the controls.

\section{Carbonylated protein detection in two-dimensional gel electrophoresis by $\mathrm{Ab}-\mathrm{HNE}, \mathrm{BH}$, and DNPH methods}

Two-dimensional gel electrophoresis (2DGE) method, which has been frequently used to visualize and identify carbonylated proteins in complex mixtures, was

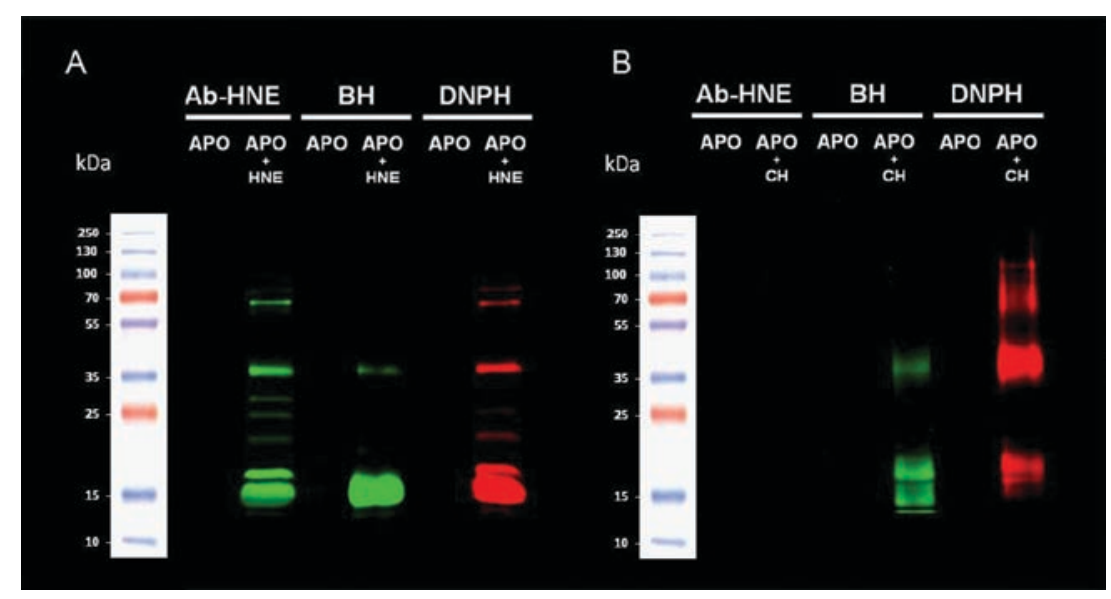

Figure 1. Western blot of in vitro oxidation of APO by HNE and CH. (A) APO oxidation using $1.3 \mathrm{mM}$ HNE; (B) APO oxidation using 1 mM $\mathrm{CH}$. Proteins were separated by SDS-PAGE (12.5\%) and transferred to nitrocellulose membrane. The modified proteins were detected by comparison to untreated APO using Ab-HNE, BH, and DNPH methods. (See colour version of this figure online at www.informahealthcare. $\mathrm{com} / \mathrm{txm})$

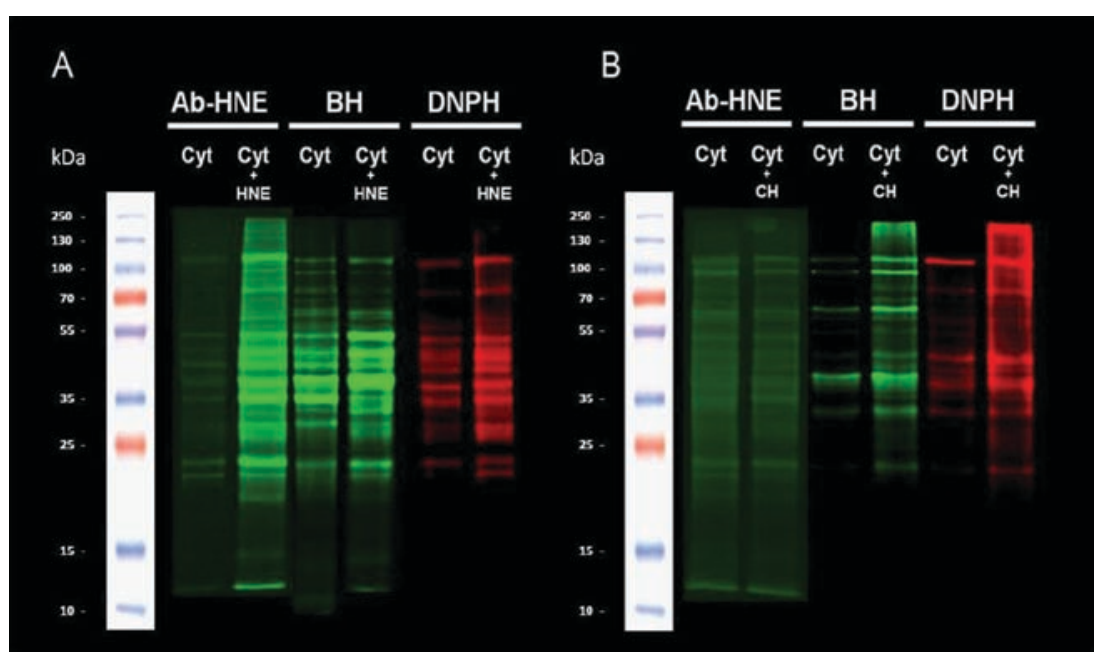

Figure 2. Western blot of in vitro cytosolic protein extracts oxidized by HNE and CH. (A) Cytosolic protein extract treated by $1.3 \mathrm{mM}$ HNE; (B) cytosolic protein extract oxidized using $1 \mathrm{mM} \mathrm{CH}$. Experimental conditions are the same as described in Figure 1. The modified proteins were detected using the $3 \mathrm{Ab}-\mathrm{HNE}, \mathrm{BH}$, and DNPH techniques described in the "Materials and methods" section and the blots were compared with those of nonoxidized cytosolic protein extracts. (See colour version of this figure online at www.informahealthcare.com/ txm) 


\section{Untreated

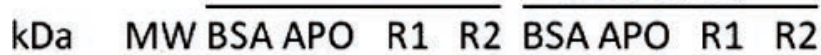

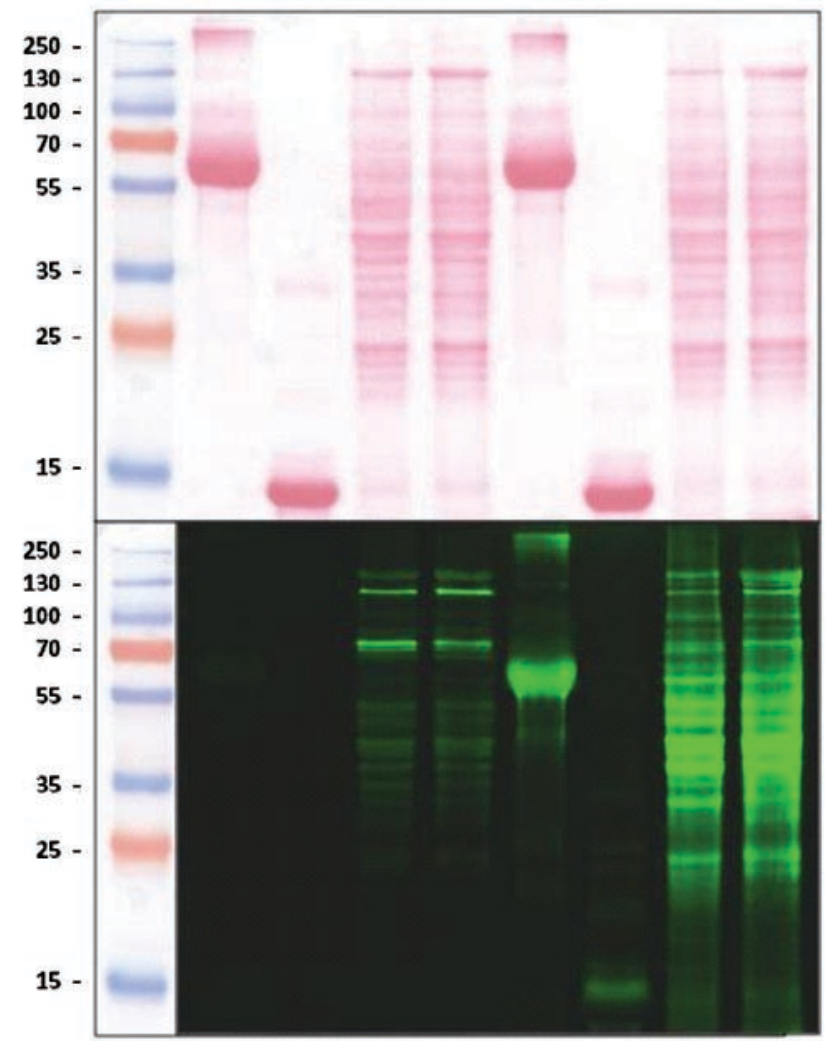

Figure 3. SDS-PAGE and subsequent blot analysis of biotinylated proteins before and after $\mathrm{BH}$ treatment. The BSA, APO, and cytosolic proteins from the liver of two different rats were treated with HNE. Samples were then treated ("BH-treated") or not ("untreated") with BH before SDS-PAGE separation. Ponceau red staining of the nitrocellulose membrane and identification of biotinylated proteins using IRDye 800-coupled streptavidin are shown in the upper and lower part of the figure, respectively. (See colour version of this figure online at www.informahealthcare. com/txm)

performed. The ability of the Ab-HNE, BH, and DNPH methods to identify directly and indirectly carbonylated proteins in the same cytosolic fraction (Figures 4 and 5 ) was compared. Separation of carbonylated proteins using 2DGE revealed an increased occurrence of each reactive protein and showed "string of pearls" shapes, which usually occurs for differently charged isoforms of similar protein backbones. This observation supports an enhanced modification of protein charges resulting from heterogeneous multisite oxidation. Using 2DGE, the results obtained by western blotting analyses with a main group of modified protein ranging from $25 \mathrm{kDa}$ to $55 \mathrm{kDa}$ were confirmed. Additional information on protein charges brought by the IEF step reveals that proteins migrating around $100 \mathrm{kDa}$ in western blot analysis are charged negatively (Figures 4 and 5). As expected, $\mathrm{CH}$-oxidized proteins were found unchanged, when tested with the Ab-HNE method (not shown in Figure 5).

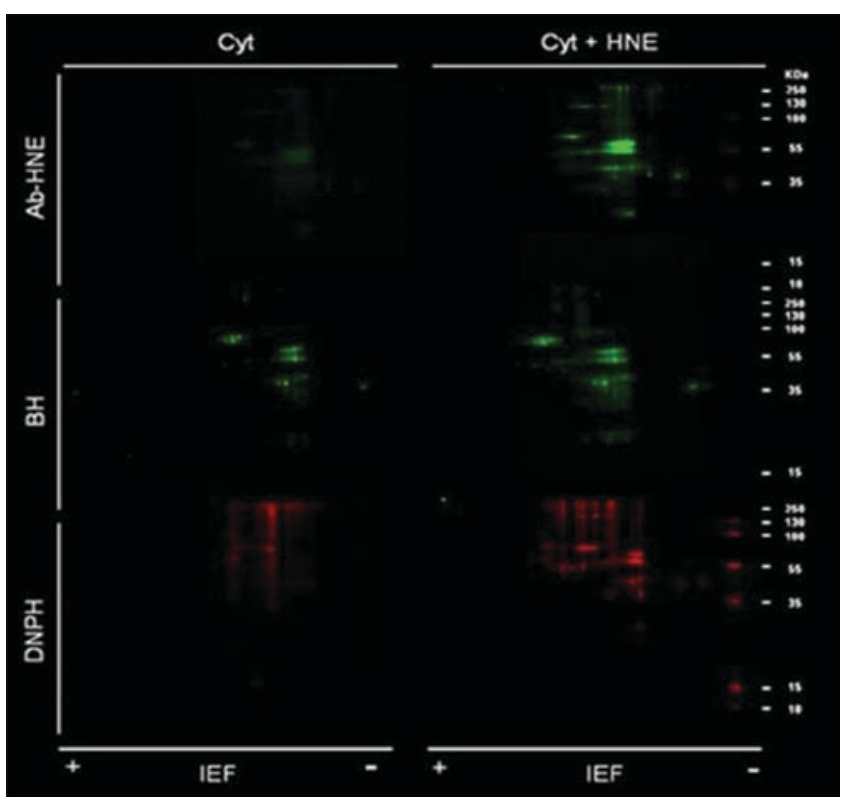

Figure 4. wo-dimensional electrophoresis blotting of in vitro treatment of cytosolic proteins extract by HNE. Separation of proteins $(100 \mu \mathrm{g})$ was performed on a $110-\mathrm{mm}$ pH 3-10 IEF gel on first dimension and $12.5 \%$ SDS-PAGE in the second dimension on $10 \times 10 \mathrm{~cm}$ gels before transfer to nitrocellulose membrane. Top: Antibody HNE-His adducts method, Middle: BH method, Bottom: DNPH method. (See colour version of this figure online at www. informahealthcare.com/txm)

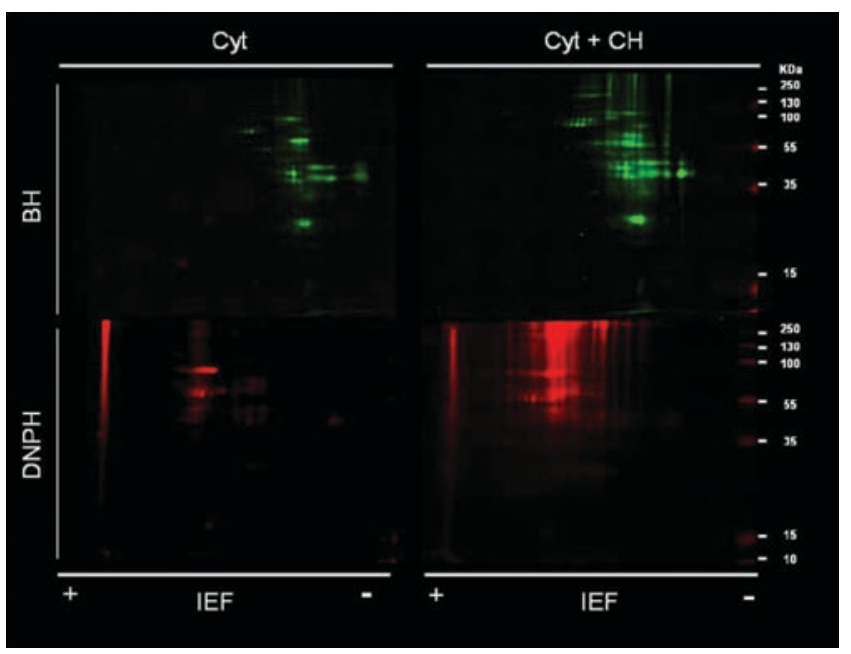

Figure 5. wo-dimensional electrophoresis blotting of in vitro oxidized cytosolic protein extracts by $\mathrm{CH}$. Gel separation is briefly described in the legend of Figure 4. Top: BH method, Bottom: DNPH method. (See colour version of this figure online at www. informahealthcare.com/txm)

\section{Discussion}

Oxidative stress is a disturbance in the balance of the redox state of the cell, inducing damage in membranes, DNA and proteins through disturbance of intracellular signaling, enzymes efficiency, and protein-protein interactions. Protein oxidation induced by oxidative stress is likely involved in the evolution of many diseases (Kohen and Nyska 2002). However, the identification of 
oxidized proteins is incomplete. Therefore, a targeted proteomic analysis of oxidized proteins is necessary to elucidate their relationships with pathological status and the protein-level mechanisms that induce disease. The potential utility of oxidized proteins as biomarkers of disease has initiated much interest in the development of methodologies to characterize protein modifications on a proteome-wide scale (Dalle-Donne et al. $2003,2006 a)$. This study reports the application of three different methods for labeling carbonylated proteins directly or indirectly for identification by proteomic analysis. Carbonylated proteins are classic indicators of oxidative stress damage. The incubation of sample proteins with DNPH can be used to measure protein carbonylation by colorimetry, inmunohistochemistry, mass spectrometry, and western blotting. The DNPH method can detect not only carbonyl groups but also specific modifications, such as HNE, acrolein, ONE, and malondialdehyde (Sayre et al. 2006). Using standard streptavidin-coupled detection techniques, $\mathrm{BH}$ has been shown to be able to detect protein carbonyl groups, including the aldehyde group of HNE when it is adducted to protein by Michael addition. On the other hand, anti-His-HNE antibodies allow specific visualization of HNE-histidine adducts either in tissues by western blot and immunohistochemistry or with ELISA techniques (Negre-Salvayre et al. 2008; Spickett et al. 2010).

First a conventional immunostaining method using an antibody that recognizes HNE-His adducts, which have been proposed as a marker for the progression of several diseases (Loguercio and Federico 2003; Reed et al. 2008) was evaluated. The results validate the efficiency of the HNE-His antibody method in a single protein assay or in a complex protein mixture by western blotting analysis or by two-dimensional electrophoresis with antibody detection. This classical method provides an easy way to identify the modification of proteins by Michael addition of HNE to His. Specific antibodies for HNE adducts have been used most for detecting HNEprotein adducts in cells and tissues. Such immunohistochemical detection of the HNE-His adducts in various human and animal tissues revealed both physiological presence of the HNE-modified proteins as well as their pathological distribution in particular in malignant (cancer), inflammatory, and degenerative processes (Spickett et al. 2010). Interestingly, comparison of the quantitative (the HNE-His ELISA) and qualitative immunocytochemical analyses in vitro with the qualitative, immunohistochemical analyses in vivo revealed the presence of the HNE-modified proteins in vivo resembling those obtained in vitro for the cell exposed to the 1-10 $\mu \mathrm{M}$ HNE concentration range (Borovic et al. 2006; Zarkovic et al. 2009). This concentration range is much above the values of HNE previously considered to be physiological $(0.1-1 \mu \mathrm{M})$ indicating physiological importance of lipid peroxidation, while specific protein modification associated with pathology of lipid peroxidation generating higher levels of HNE should be carried out as was done in this study. Namely, when APO or the cytosolic protein extract was treated by $\mathrm{CH}$, there was no detection by the HNE-His Ab method, likely because there was no fatty acid in the purified protein or the cytosolic extract to yield HNE upon oxidation. Mass spectrometric analyses of proteins modified under conditions of oxidative stress revealed that His residues are the major sites for HNE adduction in heme proteins. Liquid chromatography-electrospray ionization-mass spectrometry (LC-ESI-MS)/MS analysis confirmed that HNE adduction occurs exclusively on His residues in bovine APO (Alderton et al. 2003). Although HNE-His is not the most common HNEprotein adduct, HNE-His should reflect the increased presence of HNE during acute oxidative stress or during the late stages of chronic diseases when adduction to the cysteine thiolate pool is saturated (LoPachin et al. 2009). Some methods have been developed to evaluate HNE protein adducts on different amino acid residues (Veronneau et al. 2002; Lesgards et al. 2009). However, these methods involve sophisticated methodology and the necessary instrumentation is not widely available.

Two-dimensional electrophoresis has been used frequently for the identification of modified proteins in complex mixtures. To demonstrate the feasibility of using the HNE-His antibody, two-dimensional electrophoresis on a cytosolic protein extract treated in vitro by HNE was used. The HNE-modified protein spots could be clearly visualized after immunoblotting. The number of spots that was obtained indicated that a large number of proteins can be modified by HNE in vitro, which confirms previous data by other authors (Roede et al. 2008).

The BH method includes a detection step that uses labeled streptavidin and is based on the reaction of carbonyl groups with hydrazide to form a hydrazone. Although this is a new method, the approach based on hydrazide chemistry has been used by some authors for the enrichment of carbonyl-containing peptides obtained after modification by the lipid peroxidation product HNE (Vila et al. 2008; Codreanu et al. 2009). Here BH was employed to label the HNE adducts and other carbonylated proteins. The BH method has been reported by others to be advantageous over the HNE-His antibody method for detection of not only HNE-His adducts but also other Michael adducts of HNE and direct carbonylated proteins (Vila et al. 2008). Several authors have detected HNE-proteins with this BH method (Roe et al. 2007; Codreanu et al. 2009). However, positive staining in liver cytosolic fractions without reaction with the biotin hydrazine reagent was observed. These bands likely reveal the presence of naturally occurring biotinylated proteins. The apparent molecular weights of these proteins correspond to those of pyruvate carboxylase and propionyl-CoA carboxylase, which were previously characterized in western blots of rat liver samples as naturally biotinylated proteins (Salto et al. 1999). Thus, these artifacts are inherent in streptavidin-biotin detection systems and should be taken into 
account in the evaluation of protein carbonylation with the $\mathrm{BH}$ method.

The DNPH method was able to identify proteins modified in vitro by $\mathrm{HNE}$ and $\mathrm{CH}$. The DNPH clearly detected the HNE-His adduct formed in APO and also in the cytosolic proteins treated with HNE, demonstrating high sensitivity for not only HNE adducts but also other oxidatively modified proteins, which could correspond to carbonylated proteins. The DNPH is one of the older techniques used for detecting protein carbonylation. The use of DNPH has been reported for proteins modified in vitro and in vivo, enabling identification of carbonyl proteins in various traumatic injuries and disease states that involve cellular oxidative stress, including neuronal degeneration and Alzheimer's disease (Vaishnav et al. 2007; Butterfield et al. 2009). It is herein shown that this method is able to target both direct and indirect protein carbonylation.

The three tested methods allow a first step of evaluation without $a$ priori digestion and give spot profiles by two-dimensional electrophoresis. Image software can be used to match and analyze the protein spots visualized among differential two-dimensional gels, followed by statistic analyses to determine which of the modified proteins may have biological importance. In this way, only the proteins considered significantly different could be subjected to in-gel trypsin digestion and subsequent mass spectrometric identification analyses. In the assays used, the clearest two-dimensional image was observed when using the HNE-His $\mathrm{Ab}$ method rather than the $\mathrm{BH}$ and DNPH methods. However, staining by HNE-His Ab is recommended to specifically detect protein modifications by oxidative damage.

\section{Conclusion}

There was a need to compare methods for detection of protein carbonylation in the context of oxidative stress studies, especially when occurring through distinct direct and indirect processes. As expected, the anti-HNE antibody specifically revealed HNE adducts and not $\mathrm{CH}$-oxidized proteins. A clear separation of HNE-modified proteins using 2DGE and HNE-His Ab was observed. In contrast, the DNPH method detected both $\mathrm{CH}$-oxidized proteins and HNE adducts and could probably detect adducts coming from other bifunctional aldehydes originating from lipid peroxidation, such as 4-hydroxyhexenal and 4-oxononenal. The authors found the BH method to be less specific and to generate artifactual staining of unoxidized proteins with streptavidin coupled dyes. The HNE-His Ab and DNPH methods sound complementary: DNPH method has the advantage to give a global vision of oxidative stress consequences on cellular proteins, while HNE-His $\mathrm{Ab}$ method is ideal to get precise information concerning HNE adducts formation, particularly on low-abundant proteins. Although rather classical, methods for carbonyl detection on proteins may be biased by artifactual detections and complicated by proteins multimerizations. The use of more and more specific available antibodies in oxidative stress studies involving detection of lipid peroxidation product adducts on proteins are recommended.

Declaration of interest: This work was supported by a scholarship (VGVR173007), BECAS MIXTAS EN EL EXTRANJERO 2008 from CONACYT and ECOS-NordANUIES grant M07S03. This work was also supported by COSTB35 and the French/Croatian Program COGITO.

\section{References}

Alderton AL, Faustman C, Liebler DC, Hill DW. 2003. Induction of redox instability of bovine myoglobin by adduction with 4-hydroxy2-nonenal. Biochemistry 42:4398-4405.

Aldini G, Dalle-Donne I, Colombo R, Maffei Facino R, Milzani A, Carini M. 2006. Lipoxidation-derived reactive carbonyl species as potential drug targets in preventing protein carbonylation and related cellular dysfunction. ChemMedChem 1:1045-1058.

Aldini G, Dalle-Donne I, Facino RM, Milzani A, Carini M. 2007. Intervention strategies to inhibit protein carbonylation by lipoxidation-derived reactive carbonyls. Med Res Rev 27:817-868.

Argüelles S, Machado A, Ayala A. 2006. "In vitro" effect of lipid peroxidation metabolites on elongation factor-2. Biochim Biophys Acta 1760:445-452.

Borovic S, Rabuzin F, Waeg G, Zarkovic N. 2006. Enzyme-linked immunosorbent assay for 4-hydroxynonenal-histidine conjugates. Free Radic Res 40:809-820.

Bruenner BA, Jones AD, German JB. 1995. Direct characterization of protein adducts of the lipid peroxidation product 4-hydroxy-2nonenal using electrospray mass spectrometry. Chem Res Toxicol 8:552-559.

Butterfield DA, Galvan V, Lange MB, Tang H, Sowell RA, Spilman P, Fombonne J, Gorostiza O, Zhang J, Sultana R, Bredesen DE. 2010. In vivo oxidative stress in brain of Alzheimer disease transgenic mice: Requirement for methionine 35 in amyloid beta-peptide of APP. Free Radic Biol Med 48:136-144.

Codreanu SG, Zhang B, Sobecki SM, Billheimer DD, Liebler DC. 2009. Global analysis of protein damage by the lipid electrophile 4-hydroxy-2-nonenal. Mol Cell Proteomics 8:670-680.

Dalle-Donne I, Aldini G, Carini M, Colombo R, Rossi R, Milzani A. 2006a. Protein carbonylation, cellular dysfunction, and disease progression. J Cell Mol Med 10:389-406.

Dalle-Donne I, Giustarini D, Colombo R, Rossi R, Milzani A. 2003. Protein carbonylation in human diseases. Trends Mol Med 9:169-176.

Dalle-Donne I, Rossi R, Colombo R, Giustarini D, Milzani A. 2006b. Biomarkers of oxidative damage in human disease. Clin Chem 52:601-623.

Doorn JA, Petersen DR. 2003. Covalent adduction of nucleophilic amino acids by 4-hydroxynonenal and 4-oxononenal. Chem Biol Interact 143-144:93-100.

Doorn JA, Petersen DR. 2002. Covalent modification of amino acid nucleophiles by the lipid peroxidation products 4-hydroxy-2nonenal and 4-oxo-2-nonenal. Chem Res Toxicol 15:1445-1450.

Esterbauer H, Schaur RJ, Zollner H. 1991. Chemistry and biochemistry of 4-hydroxynonenal, malonaldehyde and related aldehydes. Free Radic Biol Med 11:81-128.

Grimsrud PA, Xie H, Griffin TJ, Bernlohr DA. 2008. Oxidative stress and covalent modification of protein with bioactive aldehydes. J Biol Chem 283:21837-21841.

Jouanin I, Sreevani V, Rathahao E, Gueraud F, Paris A. 2008. Synthesis of the lipid peroxidation product 4-hydroxy-2(E)-nonenal with 
C-13 stable isotope incorporation. J Label Compds Radiopharm 51:87-92.

Kohen R, Nyska A. 2002. Oxidation of biological systems: oxidative stress phenomena, antioxidants, redox reactions, and methods for their quantification. Toxicol Pathol 30:620-650.

Lesgards JF, Frayne IR, Comte B, Busseuil D, Rhéaume E, Tardif JC, Rosiers CD. 2009. Differential distribution of 4-hydroxynonenal adducts to sulfur and nitrogen residues in blood proteins as revealed using Raney nickel and gas chromatography-mass spectrometry. Free Radic Biol Med 47:1375-1385.

Loguercio C, Federico A. 2003. Oxidative stress in viral and alcoholic hepatitis. Free Radic Biol Med 34:1-10.

Levine RL, Garland D, Oliver CN, Amici A, Climent I, Lenz AG, Ahn BW, Shaltiel S, Stadtman ER. 1990. Determination of carbonyl content in oxidatively modified proteins. Meth Enzymol 186: 464-478.

Levine RL, Williams JA, Stadtman ER, Shacter E. 1994. Carbonyl assays for determination of oxidatively modified proteins. Meth Enzymol 233:346-357.

LoPachin RM, Gavin T, Petersen DR, Barber DS. 2009. Molecular mechanisms of 4-hydroxy-2-nonenal and acrolein toxicity: nucleophilic targets and adduct formation. Chem Res Toxicol 22:1499-1508.

Nadkarni DV, Sayre LM. 1995. Structural definition of early lysine and histidine adduction chemistry of 4-hydroxynonenal. Chem Res Toxicol 8:284-291.

Negre-Salvayre A, Auge N, Ayala V, Basaga H, Boada J, Brenke R, Chapple S, Cohen G, Feher J, Grune T, Lengyel G, Mann GE, Pamplona R, Poli G, Portero-Otin M, RiahiY, Salvayre R, Sasson S, Serrano J, Shamni O, Siems W, Siow RC, Wiswedel I, Zarkovic K, Zarkovic N. 2010. Pathological aspects of lipid peroxidation. Free Radic Res 44:1125-1171.

Negre-Salvayre A, Coatrieux C, Ingueneau C, Salvayre R. 2008. Advanced lipid peroxidation end products in oxidative damage to proteins. Potential role in diseases and therapeutic prospects for the inhibitors. Br J Pharmacol 153:6-20.

Nyström T. 2005. Role of oxidative carbonylation in protein quality control and senescence. EMBO J 24:1311-1317.

Petersen DR, Doorn JA. 2004. Reactions of 4-hydroxynonenal with proteins and cellular targets. Free Radic Biol Med 37:937-945.

Poli G, Biasi F, Leonarduzzi G. 2008. 4-Hydroxynonenal-protein adducts: A reliable biomarker of lipid oxidation in liver diseases. Mol Aspects Med 29:67-71.

Reed T, Perluigi M, Sultana R, Pierce WM, Klein JB, Turner DM, Coccia R, Markesbery WR, Butterfield DA. 2008. Redox proteomic identification of 4-hydroxy-2-nonenal-modified brain proteins in amnestic mild cognitive impairment: insight into the role of lipid peroxidation in the progression and pathogenesis of Alzheimer's disease. Neurobiol Dis 30:107-120.

Requena JR, Levine RL, Stadtman ER. 2003. Recent advances in the analysis of oxidized proteins. Amino Acids 25:221-226.
Roe MR, Xie H, Bandhakavi S, Griffin TJ. 2007. Proteomic mapping of 4-hydroxynonenal protein modification sites by solid-phase hydrazide chemistry and mass spectrometry. Anal Chem 79:3747-3756.

Roede JR, Carbone DL, Doorn JA, Kirichenko OV, Reigan P, Petersen DR. 2008. In vitro and in silico characterization of peroxiredoxin 6 modified by 4-hydroxynonenal and 4-oxononenal. Chem Res Toxicol 21:2289-2299.

Salto R, Girón MD, del Mar Sola M, Vargas AM. 1999. Evolution of pyruvate carboxylase and other biotin containing enzymes in developing rat liver and kidney. Mol Cell Biochem 200:111-117.

Sayre LM, Lin D, Yuan Q, Zhu X, Tang X. 2006. Protein adducts generated from products of lipid oxidation: focus on HNE and one. Drug Metab Rev 38:651-675.

Schaffner W, Weissmann C. 1973. A rapid, sensitive, and specific method for the determination of protein in dilute solution. Anal Biochem 56:502-514.

Spickett CM, Wiswedel I, Siems W, Zarkovic K, Zarkovic N. 2010. Advances in methods for the determination of biologically relevant lipid peroxidation products. Free Radic Res 44:1172-1202.

Stadtman ER, Berlett BS. 1997. Reactive oxygen-mediated protein oxidation in aging and disease. Chem Res Toxicol 10:485-494.

Vaishnav RA, Getchell ML, Poon HF, Barnett KR, Hunter SA, Pierce WM, Klein JB, Butterfield DA, Getchell TV. 2007. Oxidative stress in the aging murine olfactory bulb: redox proteomics and cellular localization. J Neurosci Res 85:373-385.

Valko M, Leibfritz D, Moncol J, Cronin MT, Mazur M, Telser J. 2007. Free radicals and antioxidants in normal physiological functions and human disease. Int J Biochem Cell Biol 39:44-84.

Véronneau M, Comte B, Des Rosiers C. 2002. Quantitative gas chromatographic-mass spectrometric assay of 4-hydroxynonenal bound to thiol proteins in ischemic/reperfused rat hearts. Free Radic Biol Med 33:1380-1388.

Vila A, Tallman KA, Jacobs AT, Liebler DC, Porter NA, Marnett LJ. 2008. Identification of protein targets of 4-hydroxynonenal using click chemistry for ex vivo biotinylation of azido and alkynyl derivatives. Chem Res Toxicol 21:432-444.

Waeg G, Dimsity G, Esterbauer H. 1996. Monoclonal antibodies for detection of 4-hydroxynonenal modified proteins. Free Radic Res 25:149-159.

Waris G, Ahsan H. 2006. Reactive oxygen species: role in the development of cancer and various chronic conditions. J Carcinog 5:14.

Zarkovic N, Cipak Gasparovic A, Cindric M, Waeg G, Borovic Sunjic S, Mrakovcic L, Jaganjac M, Kolenc D, Andrisic L, Gveric Ahmetasevic S, Katusic A, Cherkas A, Juric Sekhar G, Wildburger R, Zarkovic K. (2009) 4-Hydroxynonenal-protein adducts as biomarkers of oxidative stress, lipid peroxidation and oxidative homeostasis. In: Free Radicals, Health and Lifestyle. Caporossi FPD, Sabatini S, (eds.). Bologna, Italy: Medimond Srl. pp 37-45. 